\title{
Cultural democracy and schooling in India: A subaltern perspective
}

\section{Manojan K.P.}

Abstract: It is argued that educational spaces often maintain certain forms of hierarchical cultural patterns to reproduce an unequal civil society. The history and contemporary nature of Indian civil society, ridden with relations of caste and class, often interpellates its agenda of hierarchical order in the cultures of schooling. Children from marginalized communities, particularly from the Adivasi (tribal) cultures, are more vulnerable to these undercurrents, and this often results in their dispirited autonomous participation in schooling. The content and nature of the curriculum and modes of pedagogical interactions are the focal channels of its operationalization. In recent times and earlier, various forms of contestations had emerged against this dominant agenda, particularly from subaltern contexts. These took the form of democratic resistances seeking to establish democratic cultures in classrooms and schools (Apple C James, 2007; Darder et.al, 2009). Creating a sphere of this order would promise to enable children to become transformative human beings and autonomous intellectuals. Viewing the regime of education as both liberatory and oppressive (McLaren, 2009), this paper is an attempt to engage with democratic concerns in the realm of schooling in India within the relations of culture, knowledge and its politics.

Key words: cultural democracy; schooling; hegemony, Adivasi children.

\section{Introduction}

Cultural democracy, as a term and as a discourse, projects concerns towards matters of social justice and the self-respect of culturally marginalized communities (Freire, 1968, 1970; Entwistle, 1977; Giroux, 1983; Darder et. al, 2009). The concept of cultural democracy holds a crucial stake in the realm of education, where the values of pluralism, equity and human autonomy collide against the supremacy of prejudices based on race, caste, 
ethnic and regional formations (Arlen \& Don, 1990). In the history of education, across the globe, this quest has its early origins in the beginning of the $20^{\text {th }}$ century in different parts of the world. The philosophies of progressive thinkers like John Dewey and W. E. B Dubois of the United States are seen as its flagship and coincide with the trajectory of the radical educator of Latin America Paulo Freire and his critical pedagogy in recent decades. The slogans of their educational aspirations protest against the impediments of classism, racism, white supremacy, colonial domination, xenophobia and many versions of the hidden curriculum (Apple, 1980, 1993; Darder et.al, 2009). In a collective sense, these quests are said to be aimed at practices of (democratic) education which recognize the values of equality, freedom and social justice concerning the varying diversities of human cultural formations. It is contended that deviating from these ideals would create conflicts in the learning process, learning individuals and their political formations (Wringe, 1984; Apple \& James, 2007).

In the recent past, certain struggles within this milieu raised similar contentions by projecting the issues of misrepresentation and de-legitimization of indigenous knowledge systems and cultural contexts as a major slogan (Semali \& Kincheloe, 1999; Denzin \& Lincoln, 2008). For instance, one of its genres was led by the Maori tribal communities in New Zealand demanding an indigenized curriculum in schools and universities (Harrison \& Papa, 2005). Similarly, resistance and struggle have emerged among indigenous populations across the globe, such as the Samis in Canada, the Zapatistas in Mexico, the Mandarins in China and many of their counterparts, in pursuit of recognition of their indigenous cultural epistemologies (Mauro \& Harrison, 2000; Barnhardt \& Kawagley, 2005; Harrison \& Papa, 2005). At the outset, these movements were at the forefront, competing for spaces of recognition for their language, culture, identity and the varied knowledge systems in academia from kindergartens to universities (Semali \& Kincheloe, 1999; Smith, 1999, 2005). The questions they posed did not demand the formation of a new right, but protested for the recognition of rights already acknowledged by international law frameworks and rights forums such as ILO, UNDRIP, UNESCO and many other bodies within their frameworks of Cultural and Educational Rights (Burman, 1998).

Beginning from this premise, I intend to engage with the various impediments to the formation of these contentions in the larger perspective of the (tribal/ tribe of) Adivasi ${ }^{1}$ communities in India as a subaltern community.

1 The term adivasi refers to the tribal population in India administratively listed as 
By subaltern ${ }^{2}$, I mean people at the margins or populations who lack autonomous power in civil society (Gramsci, 1971; Green, 2002; Crehan, 2013). The objective of this paper lies in the right of the children of subaltern communities to engage with the educational systems, particularly schooling. The question is to what extent do the schooling processes respond to the democratic aspirations of these children, whose subjectivities are formed/ ing under multiple relations of culture, knowledge and politics. More specifically, the paper enquires into the debates on curriculum and pedagogy and its socio-political implications. The paper is divided into three sections, (1) the politics of knowledge and its imperatives in relation to the exclusion of Adivasi children (2) the dilemma embodied in the pedagogical process associated with the formal schooling structures and (3) a discussion part along with some insights from field observations.

\section{Education of Adivasis in India}

The enterprise of education, and hence knowledge, is of tantamount importance in empowering socially and historically marginalized populations. Their conditions of un-freedom are largely subscribed by the hegemonic structure of civil society, which has a history of restricting knowledge to the privileged members of society. Reproduction theories of education content hold that education systems tend to reproduce existing inequalities, while the privileged continue to enjoy the fruits and the less privileged are increasingly restricted from accessing opportunities available to the privileged (Althusser, 1970; Bourdieu, 1973; Anyon, 2011). The history of social progress in India is also one of a dichotomy of unequal social access among populations divided across class, caste, ethnic and regional differences. It is argued that the subaltern societies such as the Adivasis are more vulnerable to this and are becoming subject to its various manifestations in educational settings (Heredia, 1992, 1995; Choudhury \& Patnaik, 2008; Radhakrishna, 2016). Active interaction between the delivering and receiving ends is prerequisite to any form of democratic participation. Here education as a site of power restricts the autonomous participation of the children of subaltern

Scheduled Tribes (ST). Terms like Girijan, Gothravasi, Vanavasi and Adivasi are used interchangeably to denote the tribal populations. Recent academic and tribal intellectual collectives tend to use 'Adivasis' as the accepted term.

2 The term subaltern is used to describe marginalized communities and was popularized after Antonio Gramsci's writing on Italian history and politics. By subaltern, Gramsci meant the working class, poor, women and other marginalized groups under the hegemonic social order (Gramsci, 1971). Although it is a politically loaded term that invites critique and debate, I use it to denote the Adivasis as the most marginalized group in Indian society. For reference, see Green, (2002); Crehan (2013). 
societies through rigid and unwelcoming operatives (Freire, 1968, 1970). A perspective of this genre aims at the significance of democratic platforms in educational settings in enhancing and empowering marginalized children to become transformative human beings. Bringing the premise of this debate in India, we have profound examples in the contemporary scenario of the disparities in education for historically disadvantaged societies, which has inevitable affinities with the questions of cultural plurality and democratic concerns (Balagopalan, 2003, 2003, 2003a; Chatterjee, 2004; Govinda, 2002; Kumar, 1985; Sarangapani, 2002; Sujatha, 2002)

Adivasi communities in India have experienced exploitation and marginalization throughout their history (Choudhury \& Patnaik, 2008; Radhakrishna, 2016). Although these communities have heterogeneous identities and are of a distinct social and cultural formation, they have all undergone severe levels of dispossession, losing land, forest and other natural resources as well as their autonomy in the domains of public and civil life (Xaxa, 1999, 2016; Kannabiran, 2016). Land alienation, caste/ ethnic domination, and deprivation were coupled with the impediments under colonialism. Adivasis in India account for more than $8.2 \%$ of the total population live in more than 600 communities across regions (GoI, 2011). In post-independence India, the central and state ministries implemented various policies and programmes aimed at empowering Adivasi communities in different tribal areas. The development of Adivasi populations was the subject of various debates. The 'integration', 'assimilation' and isolation' debates were prominent in this, which led to debates on the subjective conditions of the Adivasis communities as the citizens of the welfare state mechanisms (Choudhury, 1982; Shaw, 2005). The juncture of conflict in this debate was the nature of centrality in these horizontal policies implemented against the real and democratic aspirations of these heterogeneous communities. In this milieu, the formal systems of elementary schools are a structure of contradiction for Adivasi children. If we take into consideration the social progress of socio-economically marginalized communities of Dalits, adivasis, backward castes and Muslims, the stagnation among Adivasi communities is more visible (Jena, 1991; Nambissan, 2002; Sujatha, 2002; Pradhan, 2004; Shaw, 2005). This juxtaposes the positional difference of Adivasi communities against the effectiveness of educational and empowerment programmes. Other than the structural determinants of economic and social hindrances, I would argue that there is a larger implication in their cultural and historical formation which is being jeopardized by the regime of schooling. 
One of the premises of this predicament is the conflict between traditional communities and modern forms of schooling. It contains the argument that the horizontal model of schooling devalues or derecognizes the cultural milieu of marginalized sections and their epistemologies (Singh, 1995; Sarangapani, 2003a; Sundar, 2010; Manojan, 2018). In policy frameworks, although there are protective and welfare measures for Adivasis and Dalits, the public psyche of Indian society is not mature enough for them to be considered people of equal status with the mainstream (Janu, 2017). Education as a miniature social system resembles this presumption in more or less equal form. Taking schools as the site of interaction, most of the studies indicate that Adivasi children are considered strange and second-grade individuals in the classroom and surroundings (Varghese, 2015; Manojan, 2017,2018 ). These mechanisms operating in the systems of education often tend to perpetuate the interests of the dominant order and create social conditions that silence the spaces of critical engagement and resistances against its legitimacy (Kumar, 1991; Chintis, 1977\&1981). This is precisely how the 'agenda of marginalization' is pursued in the regimes of education (Gupta, 2012). The voices of critique and the senses of resistance are supposed to be acquired through the praxis of education. Yet, education replicates it, maintaining its structures of domination and creating subjugated subjectivities (Heredia, 1992, 1995; Manojan, 2018a).

Numerous research and studies conducted in this field report the incidents of marginalization and exclusion in several spheres of schooling (Kumar, 1985, 1989; Patel, 1991; Jena, 1991; Sachidanandha, 1999; Rani, 2009; Narayana, 2010; Nambissan \& Rao, 2013). In the historical angle, certain studies contend that the current systems and practices of Indian education are a by-product and legacy of the colonial British Empire, which is still pervasive in propagating the colonial ideals (Kumar, 1989, 1991; Krishnaswami, 2001). It persists in creating disadvantageous conditions for the children, particularly for the ones from subaltern strata where the blind imitation and implementation of the dominant ideals of the curriculum give preference to a world and knowledge system of uneasy acquaintances $(\mathrm{Ku}-$ mar, 1985; Sundar 2002). Some of the most recent studies on Adivasi education signal that Adivasi children are deeply discouraged by uninteresting curriculums, resulting in high drop-out rates, absenteeism and passive participation (Sundar, 2002, 2010; Balagopal, 2003, 2003, 2003a; Narayana, 2010, Manojan, 2018).

A generic reading of the recent research on this theme highlights three major dimensions to the main predicaments the educational project has 
for weaker sections (Patel, 1991; Jena, 1991; Heredia, 1992; Nambissan, 1994; Sridhar, 1996; Sachidanandha, 1999; Govinda, 2002; Sujatha, 2002; Rani, 2009). The first array of findings encompasses socio-economic problems relating to poverty that force children to help in the home and to assist parents with farming and other occupations. Secondly, there are structural constraints affecting schooling and Adivasi culture. The exclusionary attitudes shown by non-Adivasi school teachers and peer groups create stigmatized attitudes towards the life and culture of the Adivasi communities and children. In addition, the medium of pedagogic instruction and informal communication is the official state languages, and this has a hegemonic influence vis-à-vis the traditional dialect of these children causing alienation and estrangement. The holidays and vacations are incompatible with the seasonal cycle of Adivasis, which is more important to them than going to school compounds, presenting another conflict in their engagement with the schooling routine. The third category locates the discrepancies in the planning and management of various policies and schemes for educating tribal children. The failure in the organization of multiple administrative departments to implement the various schemes often makes the well-designed projects seem removed and ineffective.

\section{The Knowledge Question}

In the history of Indian education, colonialism is considered a major turn structuring the present education system and associated regimes of knowledge. The modern conditions scribed by the colonial ideals have created a sort of standardization and homogenization within the Indian education system (Chatterjee, 2004; Kumar, 1991). It is argued that the pluralistic trajectories of indigenous education in India were disrupted under the tutelage of the colonialist regime (Dharampal, 1982). The logic of a homogenized system of practices has propagated monolithic forms of knowledge in contrast to the diversified mass of varied cultural contexts, which it is argued results in the establishment of 'an epistemological and ontological hegemony' through its organs (Guptha, 2012). This led to circumventions that marginalize and suppress certain forms of knowledge through selective tradition, implicitly restricting particular forms of knowledge that do not correspond to 'the official' and 'the valid' ones (Apple, 1980). Notably, the missionary education in India reflecting various colonial regimes has spread across rural and urban areas and created momentum in expanding education services. But it is also contested for its stake in the imperatives of colonial modernity and its endorsement of a methodology of the dominant West (Pal \& Chakraborty, 2001). There is a debate around the intervention of colonial as well as other 
Christian missionaries on the grounds of their implicit/explicit evangelical agenda of propagating religion in remote rural areas and specifically among Dalit and Adivasi communities (Heredia, 1995a). Conversions to Christianity are considered evidence of this argument and vigilance is pervasive from the Hindu right political front even now (Choudhury \& Patnaik, 2008). But a pertinent argument is that historically the missionary educational project throughout the twentieth century created a large community of educated people, mostly from the socially and economically marginalized strata, especially in the region of South India. Predominantly, it is apprehended that the missionary education systems were not terribly successful in providing justice for the marginalized sections and, on the contrary, they endorsed the dominant class-caste order by misrepresenting and underrepresenting the disadvantaged sections in society under their implicit agendas of religious propagation (Pinto, 2004; Panikar, 2006).

During the reign of the colonialism, the country witnessed several instances of counterhegemonic interventions and interrogations from intellectuals of the subaltern social strata against colonial as well as casteist dominations (Deshpande, 2002; Rege, 2010; Zene, 2013). Mahatma Joti Rao Phule, in the early stages of colonial educational advancement, perceived this predicament and put forward his vision of liberatory education in a highly dialectical perspective (Sunny, 2014). He considered the subaltern masses' aspiration for knowledge in a two-fold frame. He urged for educational institutions to be established in rural areas for the artisans, workers, peasants, women and other underprivileged populations under the Brahmanical social order. Simultaneously he critiqued the hegemony of the dominant caste ideals in the existing knowledge frameworks and its teaching through the teachers of the dominant strata (Rege, 2010). He advocated for knowledge that recognized the artisans, the working classes and their culture of labour. Essentially, it was an ambitious system integrating the potential of their manual labour and the possibilities of exploring their intellectual imaginaries. In fact, his presumption was profound in its utmost recognition of the culture of the toiling masses and emancipatory will in knowledge through education. Similarly, we can see the same current in the works of Gandhi, Gramsci, John Dewey and many others. Mahatma Gandhi, for instance, highlighted the necessity of appropriating the culture of the labouring class and its potential to attract the interest of the artisans and workers in education (Gandhi, 1917; Lohia, 1963). But Gandhi's formulation invited critique for the lack of emancipatory vigour in questioning the oppressing social structures (Teltumbe, 2018). 
In the later currents, the post-independent slogans of homogenized unity under the umbrella of nationalism perpetuated the image of a homogenized Indian through policy frameworks and curricular organs (Kumar, 1991; Manmar \& Madhu, 1999). Though there have been significant improvements in addressing this issue, it is contended that these measures have failed to address the subaltern life experiences, languages and the knowledge system in its different education policies (Singh, 1995; Nambissan, 2002; Sujatha, 2002). The National Policy on education (1968), NPE (1982) and POA (Programme of Action, 1992) could not do justice to this cause, other than providing lip service to those nuances. NCERT textbooks were the medium for propagating this agenda in different parts of the nation. It is argued that there were various instances in which knowledge forms in the classroom dangerously misrepresented Adivasi children and their culture. For instance, Krishna Kumar (1985) narrates a classroom representation in which Adivasi children were represented as symbols of backwardness, filth, and as groups holding subjugated positions in the society. For example, the Adivasi are commonly perceived to be a people living in the interior parts of the world, practising superstitions and black magic and posing obstacles to the progress of society. Remarkably, in another front, he describes two anecdotes from the Hindi textbooks in Madhya Pradesh. The first one is the story of an Adivasi boy, Eklavya, who cuts off his thumb as a Dakshina (offering) and presents to the Acharya (Guru-teacher), who is entitled to teach archery to the children of royal families. The story portrays Ekalavya as an obedient fellow and illegitimate disciple of the Acharya, who in turn tactfully ignores the aspects of discrimination shown towards a Bhil boy. There is another narrative, about another Adivasi youth who saves a forest officer from a buffalo and is admired by the officer for his braveness and timely intervention as a saviour. These two instances are examples of the imperative of the hidden curriculum (Apple, 1980; Anyon 1980). The pervasiveness of the hidden curriculum in terms of the logic of misrepresentation of Adivasi children and their life worlds still functions as a major cause of children's disinterest and drop-out levels in formal education settings (Singh, 1994\&1995; Sarangapani, 2003a; Rani, 2009; Manojan, 2017, 2018). The above instances demonstrate how the symbolic structures of domination create an ideal moral that citizens are always in search of admiration from the dominant sections. It also implies that those who are not the recipients of admiration are less qualified or insufficiently moral to be ideal citizens (Kumar, 1991).

This is one instance in which the life of the Adivasi is represented through textbook knowledge, and of textbooks being considered as doctrines of real and authentic fact beyond the scrutiny and criticisms (Manojan, 2018a, pp. 
163-187). The crucial point here relates to introspection over the legitimacy of knowledge, to questions like who decides and who determines the validity and legitimacy of curricular knowledge (Dharak, 2012). It is the exercise of power by the dominant class and caste relations to reinforce the obedient psyche of the oppressed masses. This hegemony of textbook knowledge also contributes to structuring the minds of the learners as a process of manufacturing consent (ibid). This also applies to the notions of the middle class and capital-driven ideals propagated through textual knowledge that cultivates aspirations among children by highlighting the individualized achievements of middle-class society (Enstwistle, 1977). The operationalization of hegemony is much more visible here, where the system is capable of inventing the dreams and aspirations of the subaltern (Gramsci, 1971, Thomas, 2013). The processes of framing curricular knowledge involve certain platforms that make it legitimate. The processes of selection, codification, and transmission are decided under the tutelage of the (dominant) interest groups and their preferences. Michael Apple (1993, p.5) argues that the curriculum cannot be seen as the innocent arrangement of knowledge forms. Rather, it is the result of a selective tradition; a tradition in which selection and legitimization are executed by some sections, and more importantly, by degrading the knowledge of the powerless.

Once this is apprehended, there is a need to address the implications of this hegemony over knowledge within the curriculum as it acts in conflict with the learning experience of the children of subaltern strata. In the early discussions and debates on Adivasi education, it was lamented that the curricular knowledge creates a sense of estrangement in Adivasi children towards learning experiences because it has information that is alien to their life and culture (Kumar, 1985, Sachidanantha, 1999; Deep, 2010). The perspectives of the learner are barely accounted for in the planners' intentions, which thus represent a lame vision of the plurality of languages, cultures, and socio-economic statuses of the learners (Kumar, 1985). Here there are two regimes in contestation: one being the agency of Adivasi children, and the other the politics of marginalization they represent. As mentioned earlier, the contents of the curriculum are much more acceptable to students from the upper strata of society and in turn, this mainstreaming eventually leads the lower strata children to feel alienated and less engaged in learning. As a result, Adivasi students, largely, fail to develop their innate cognitive abilities derived from their socialization and experiences. In process, these children are forced attach with the concepts and operations mechanically without involving in the active process of constructing knowledge. This context, raises the question of the autonomy of the child towards his/her op- 
portunities to learn completely. Learning in these contexts allows partial autonomy for these children to access the knowledge in a critical form. Once they fail to grasp something in its complete form, they become demotivated from probing or questioning specific forms of knowledge. This lays down the conditions that gradually impair the child's ability to ask questions or critique and criticize.

\section{The Process of Learning and the Politics of Experience}

Learning is a process of developing perspectives over given knowledge through understanding, dialogue (discussion) and reflection (Freire, 1968). Here, the three aspects of understanding, dialogue, and reflection require amounts of cognition largely bounded to one's intellect and experience. John Dewey, the champion of progressive education, envisioned the process of learning and its relation to children's experiences (Dewey, 1930). He focused upon the importance of experience in the learning process and insisted on a pedagogy that recognizes and encourages students to reflect on and understand social realities. Thus, the learners, the students, can engage freely with the social and political environment to construct knowledge with a sense of freedom (Dewey, 1916, 1930). Dewey considered 'experiences' as the major path to acquiring knowledge, and through action and participation. In other words, he was concerned more about the process than the content. In a way, learning is the reconstruction and reorganization of experiences by adding meaning to new experiences, and further learning from newer experiences. It is central to the thinking of Freire, as he emphasizes the basis of learning as the process of attaining critical consciousness or conscientization, which is an act of active engagement. It requires the rejection of the conditions of objective learning and requires learners to become the subjects of the learning process, in which the potential of experience becomes an important aspect of learning (Freire, 1970).

When we discuss formal knowledge structures, it is contended that they create opportunities for subjugating the agency of Adivasis and their knowledge systems acquired through generations. Their life experiences are seldom considered and are devalued by establishing certain hegemonic pedagogic ideals as the official and valid ones. According to Paulo Freire, this is an effort by the dominant section to deny the participation of the marginalized in acting as full human - the ontological vocation of the human being (ibid, p.32). He argues that the task of human beings is to enter into the social reality and participate in the dynamic processes of making histories according to their capabilities. In contrast, when the society continues to oper- 
ate under the domination of the elite and superior forces, the participation of the downtrodden sections takes place under passivity and dependency. In a way, the dominant sections tend to monopolize the process of making histories by silencing a large section of the population as passive elements. Paulo Freire terms this the process of 'assistencialism' (Freire, 1968, pp.2936). He explains that there are two dangers in this: first, it contradicts the natural vocation of a person being a natural subject and treats him or her as a passive object. Secondly, it contradicts and violates the fundamentals of democratization

The propagation and glorification of dominant imaginaries produced through textbooks and pedagogies, for instance the narratives or stories in the primary curriculum quite often are about kings, warriors and privileged heroes and their triumphs of monopoly (Kumar, 1985). Their lifestyles, language and morals are given as examples of good elements in society. This often leads to the formation of common sense opinions that victories in life are restricted for the privileged ones. These corollaries further result in the creation of another sense of 'subjugated other' within the learner: that he or she is in no way a part of history and that history is for the privileged. The life and experiences of the subaltern reduce to something 'less valued' at the intellectual grading of the dominant mainstream and are excommunicated from the 'real' and 'valid'. The child's cognition is constrained within the contours of certain authentic codes of textbook knowledge and there is an intense devaluation of spaces for the learner to think and connect with their memory and experience. The environment and the culture the children live in contributes to their sense of knowledge, but it does not have an authentic space in classrooms. The possibilities of invoking these memories constitutes the political process of cultivating resistance within them. Giroux argues that the politics of memory has to establish the power of local histories through the critical mode of remembering it. These episodes of encounters inaugurated at the cost of subjugated knowledge forms must be seen as a counter-memory against the hegemony of authoritative knowledge. Moreover, these aid learners in creating new forms of critique and self-respect by identifying the power within them through an act of liberating remembrance' (Freire, 1970; Giroux, 1983).

There is a dilemma between the mediums of instruction and the Adivasi children's traditional dialect, where the classroom pedagogic transaction often takes place in the approved language common in the region, either in the state language or other dominant language. For most of the Adivasi children, neither of these languages is their primary language or mother tongue. 
In India, there are more than 450 Adivasi groups with different dialects as their mother tongue (Devy, 2013). Most of them have no written form. Even Adivasi groups like those found in the Bhils and Santhals compounds, accounting for a population of more than five million with their own dialect, are taught in Hindi, Marathi or Gujarati in the states of Rajasthan, Maharashtra and Gujarat respectively (Ommen, 2012). (There have been some recent efforts to consider their language as a pedagogic medium). This is the common situation of the majority of Adivasi children in formal schools. These children are forced to learn other languages at an early learning stage, which creates a sense of alienation in learning experiences. On the other hand, the imaginaries of the verbal exercises, grammar and syntaxes in the new language would appear to resemble their lived experiences and everyday practices. In terms of policy frameworks, there is still no mother tongue education for Adivasi children (Sujatha, 2002; Devy, 2013). The rejection of the dialect they acquired through natural socialization and being compelled to learn a new grammar causes significant discouragement among the children and is a major reason for them dropping out (Mishra, 1996; Chattarjee, 2004).

The issue of language is not just an issue limited to learning but has wider political implications within the regime of culture and rights of the culturally marginalized social groups (Sridhar, 1996). The neglect of the languages of marginalized communities has two effects: firstly, it leads to troubling experiences in the learning process, and secondly, it subjugates the potential within the lore of indigenous languages, which eventually leads to the erasure of oral traditions acquired over generations. Kishore Dharak (2012) argues that there is a larger politics of 'purity and pollution' embodied in the agenda of homogenizing and formalizing dominant languages. The languages of the upper caste/class are validated by devaluing the languages of the subaltern masses as unclean folk ways. He illustrates this with an example of a class eight Marathi language classroom. The teacher was narrating a story about the life and hardships of a de-notified nomadic tribe written by a Dalit writer. Soon after narrating the story he gave an exercise for the students to find the tribal language (Boli bhasha) in the story and to rewrite those into in standard Marathi language. This instance replicates the linguistic pleasure of the Brahmanical interest in celebrating their privileges by ascribing a low status to the subaltern adivasi languages and to establishing the purification processes to become a valid language (ibid).

Like in any society, the contradiction between the cultures is explicit here. Languages, being the carriers of culture, are not free from the dynamics of 
power relations in reproducing the dominant forms. McLaren and Giroux (1995) depict the need to establish the potential embodied in the culture of the marginalized. In the same way, the subaltern cultures also have the potential to mobilize their contesting power to demolish the contributing structures of domination and oppression and to foment resistance among the subaltern. This should be the collective resistance of organic intellectuals within academia using language as the major tool. In this sense it is similar to the prime need to recognize the varied social contexts behind the creation of languages as a part of the culture and as a component bounded to their everyday forms of interactions and resistance forms. It implies that the educator's task is to link the experiences of the children to the official curriculum by unravelling the criticalities in it. Learners should be educated about the possibility of their own languages to challenge the hegemonic language forms. Importantly, the memories, experience and life of Adivasis exist within their cultural orbits, which enriches their self-respect, and selfeducation (Shor, 1993) would catalyse them to challenge the instances of de-recognition and exclusion.

\section{The Need for Departures}

The process of schooling is seen as the sites of hegemony wherein these spaces exercise the perpetuation of common-sense ideals on a par with the dominant mainstream images. For Gramsci, education is the means to produce intellectuals from the subaltern social groups who would be capable of opposing and transforming the existing social order. Throughout the process of instruction, the learners internalize the process of mechanically reviewing abstract notions and experiencing pure passivity. This becomes dangerous when the abstract notions become true for the learner's consciousness and later become part of the mainstream common sense (Gramsci, 1971). The responsibility here lies with the educator who should unravel the absurdities inherent in the schooling process and help the learner acquire a good sense of critical understanding. It is the duty of educators to make those sites of hegemony democratic spaces by being transformative intellectuals (Darder, et.al, 2009; Mayo, 2010; Anyon, 2011).

In the classroom especially, the process of learning revolves around the ability of the children to reproduce what they have heard in the previous class. The task is to identify who has learned something and who has failed, while explicitly neglecting to interrogate what the learner has learned $(\mathrm{Ku}-$ mar, 1985, Sundar, 2002; Balagopal, 2003 a). This is a suffocating practice, would estrange the children from the process of becoming their true self. 
This would also prevent the formation of their critical agency which are built around the complex processes in society and in response to educational settings. The mediocre practices of instruction do not help learners discover their critical agency until and unless the dominant education practices are driven out of the pedagogical circle. In a context like this, the educator must be capable of unravelling these historical complexities and should help the children identify their historical agency, thereby guiding them so they can become the organic intellectuals from the subaltern masses (Gramsci, 1971)

As Freire (1970) established, there is a strong presence of a hierarchical power structure between the teacher and the learner. The power structure and authoritative agency privileging the educator have to be broken. Such a departure would call for a dialogic interaction between the teacher and the learner, enhancing their ability to engage without power barriers. Essentially, this is a call for freedom within the classroom, where the teacher has always appeared as a delegate of authority (both in knowledge and in the State power). It is a call for freedom from bondage within the binaries and for the organic potential of genuineness. Moreover, yes, genuineness can create conditions capable of breaking those structures of formalities by celebrating the informalities that used to occur among human beings.

The three terminologies here, informality, freedom and genuineness, are I feel worth elaborating in the context of Adivasi children. For this purpose, I looked at the case of children from the Paniya communities (Santhosh, 2008) in Kerala who dropped out of school $^{3}$ (Manojan, 2017; Manojan, 2018a). Paniya children generally enjoy an enormous amount of freedom within their communities (Manojan, 2018a). The community places almost no serious restrictions on their leisure in play, singing, hunting, wandering and many other childhood pleasures. Parents, as well as the community people, tend not to stop or discourage children from doing any of these things; parents do not advice against these things and so they literally have absolute freedom to celebrate their childhood. Moving from an environment like this to a place that is restricted and controlled within the walls of the classrooms presents great difficulties. The school bells indicating the start of the interval convey the temporality of their freedom. Possibly, in a micro sense, the formalities of disciplining involved in these spaces create frustrations and discouragement within the child. The norms of engagement,

3 Inference from my PhD fieldwork by in Wayanad District in Kerala (Manojan, 2018a). The Paniyars are a numerous Adivasi community in Kerala mainly inhabiting the Wayanad District in the Western Ghats Region of South India (Santhosh, 2008). 
divisions of gender on the bench, and the instances of humiliations within the school atmosphere prevent them from becoming genuine learners. Also, in most cases, the authoritativeness of the teachers creates fear among the children and they feel trauma during schooling. These conditions are one of the determinants of the drop-out rates among Paniya children (Narayana, 2010; Manojan, 2017). Once they are out of school, the children move freely within their habitats and often refuse to return to school and reject appointments or compromise, while the teachers visit their homes to make them come back to school. Dropping out can be viewed as an act of withdrawing or escape by the children from a structure that tortures and discourages them from attending the educational setting for a period of time.

There may be different perspectives on how to approach this predicament in educating children from Adivasi communities. The crucial question is how we can prioritize the contexts in engaging with this. The process of formal structures undeniably fails at the two poles: in school, it fails to accommodate the Adivasi children in many domains concerning the delivery of knowledge and acceptance of the children. Simultaneously, on the other hand, the Adivasi children cannot identify with or and relate to the school practices and environment since it denies them their autonomous and active forms of participation. Thus, it would be democratic if we looked into the realm of schooling with optimum concern for the experience of the student subjected to all these sorts of hegemonic operations. The need might be for a radical restructuring of the existing practices, incorporating people's concerns and choices through democratic investigations. Such attempts can create the conceptions of democratic practices in the form of the 'pedagogies of insubordination' (Giroux, 2009) that facilitate liberation and emancipation as per their needs and aspirations.

\section{Concluding Remarks}

The above discussion was aimed at looking at the importance of education for Adivasi children. Certainly, education is about the optimum necessities, but how does it take place in the classroom? In what forms are the subjectivities of Adivasi children being constructed within the prescribed agenda of marginalization? I would argue that a turn in interrogation is inevitable in the current context. A variety of research findings and experiments confirm that Adivasi children lag behind in educational attainment. How many Adivasi students are able to access the best of higher education and employment in reputable institutions and organizations? How many intellectuals come from the various Adivasi communities across the regions? There are 
many further questions. These are not just issues related to an attitude of 'apathy' but also to the question of the 'political' behind the subjugation and discrimination.

It can be argued that in their forms of structures of discipline and norms of formalities, the spaces of schooling tend to deny genuine performances, the joy of freedom and the autonomous learning processes of these children. The task is to liberate those spaces from the imperatives, control and formalities, and transform them into spaces of active engagement and informal interactions. This project entails a dialectical vision of the schooling process and educational settings within the larger realm of civil society following the pedagogies of love and freedom. McLaren (2009) reminds us that schooling should not only be seen as a place of indoctrination or socialization; rather it must be understood as a space of heterogeneous cultural entities that facilitates students' empowerment and self-transformation. It must be understood as two aspects of power dynamics. The first is the school as a platform which works around the causes of social justice and empowerment and the other is a terrain for reproducing the dominant class interest of making the obedient subjectivities.

In this paper, I do not subscribe to an essentialist view of Adivasi cultures as divine and free of criticism nor do I suggest the dogmatic inclusion of indigenous knowledge systems in the curriculum is a panacea for the issues Adivasi children face in schooling. Rather, I attempt to make a position on the nature and relevance of cultures and its politics. The milieus of their everyday social formation point to a need to facilitate their learning strategies in formal education endeavours. The continuing terrains of exploitation and marginalization should be responded to in such a way that creates conditions for combatting these structures by enabling children to participate and develop autonomously as equal to all learners who are privileged by certain historical conditions. The transformative possibilities in educating Adivasi children must not be seen from an apathetic or pessimistic angle, but drawn on in such a way that education cultivates synergies to combat those terrains of 'epistemic violence"' occurring within the plural society of altered power equations.

4 Epistemic violence, according to Spivak (1988, p. 298), refers to the fact that subaltern people cannot speak with their full potential until they can express their views, and nobody but they can express their true self. The life worlds of the subaltern cannot be translated into the language of sciences and, philosophy until these sites are controlled by the dominant epistemologies. She visualizes this hegemony as 'epistemic violence' over the subaltern (Spivak, 1988). 


\section{References:}

Althusser, L. (1971). Lenin, philosophy and other essays. London: New Left Books. Anyon, J. (1980). Social class and the hidden curriculum work. Curriculum Inquiry, Vol (1).

Anyon, J. (2011). Marx and education. New York: Routledge.

Apple, M. (1993). The politics of official knowledge: Does a national curriculum make sense? Teachers College Record, 95(2), 1-16.

Apple, M. (2004). Ideology and Curriculum. London: Routledge Falmer

Apple, M., \& James A. B. (2007). Democratic schools: Lessons in powerful education. Portsmouth NH: Heinemann.

Arlene, G., \& Adams, D. (1990). Cultural policy and cultural democracy in G. Arlene, $\&$ D. Adams (Eds.), Crossroads: Reflections on the politics of Culture. CA: DNA Press. Balagopalan, S., \& Subrahmanian, R. (2003). Dalit and Adivasi children in schools: Some preliminary research themes and findings. IDS Bulletin, 34(1), 43-54.

Balgopal, S. (2003). These children are slow: Some experiences of inclusion, formal schooling, and the Adivasi child. Perspectives in Education, September 2003.

Balgopal, S. (2003a). Neither suited for the home nor the fields: Inclusion, formal schooling, and the Adivasi child, DS Bulletin, 34 (1). Sussex: Institute of Development Studies.

Barnhardt, R., \& O Kawagley. (2005). Indigenous knowledge systems and Alaska native ways of knowing. Anthropology and Education Quarterly, 36 (1). 8-23.

Bourdieu, P. (1973). Cultural reproduction and social reproduction. In R. Brown. (Ed.), Knowledge education and cultural change (pp.73-84). London: Tavistock.

Burman, Roy, B.K. (1998). Draft United Nations Declarations on the rights of indigenous peoples. In B.K Roy Burman, \& B.G. (Eds.), Aspiring To Be: Tribal/Indigenous Condition. Varghese, New Delhi: Konark Publishers.

Chattarjee, A.V. (2004). Education and Democracy in India, New Delhi: Manohar Publishers.

Chintis, S. (1977). Education and inequality. In A. Klsokoswka, \& G. Martinitti. (Eds.), Education in a changing society (pp 73-106). London: Sage.

Chintis, S. (1981). A long way to go. Bombay: Allied Publications.

Choudhury, B. (1982). Tribal development in India. New Delhi: Inter India Publications.

Choudhury, S. M., \& Patnaik, S. (2008). Indian tribes and the mainstream. New Delhi: Rawat Publications.

Crehan, K. (2013). Living subalternity: Antonio Gramsci's concept of common sense. In C. Zene (Ed.), The political philosophies Antonio Gramsci and B. R. Ambedkar (pp. 103-115). London: Routledge.

Darder, A., Baltodano, M., \& Torres, R.D. (2009). The critical pedagogy reader. New York: Routledge.

Deep, P. (2010). The politics of tribal education and governance: The Orissa experience. In Y. Chinna Rao, \& Sudhakara Karakoti (Eds.), Exclusion and discrimination: Concepts, perspectives, and challenges. New Delhi: Kanishka Publishers.

Denzin, N.K., \& Lincoln, Y.S. (2008). Critical methodologies and indigenous inquiry: handbook of critical and indigenous methodologies. New Delhi: SAGE Publications 
Deshpande, G. P. (2002). Selected writings of Jotirao Phule. New Delhi: Left Word Books.

Devy, G. N. (2013). Culture and development, an experiment with empowerment, Field Actions Science Reports, Special Issue 7; accessed at http://journals. openedition.org/factsreports / 2404

Dewey, J. (1916). Democracy and education. New York: Mc Millan.

Dewey, J. (1930). The school and the society. New York: Mc Millan.

Dharak, K. (2012). Prescribed marginalization, Seminar, October.

Dharampal (1982). The beautiful tree. Goa: The Other India Press.

Entwistle, H. (1977). Class culture and education. London: Methuen.

Freire, P. (1968). Education for critical consciousness. London: Continuum.

Freire, P. (1970). Pedagogy of the oppressed. New York: Continuum Publishing House Gandhi, M.K. (1917). Collected works of Mahatma Gandhi (Vol. 13). New Delhi: Publications Division, Government of India (Republished in 1998).

Giroux, H. A. (1983). Theory and resistance in education: Pedagogy for the opposition. South Hadley, MA: Bergin \& Garvey.

Giroux, H. A. (2009). Critical theory in Educational Practice, In A. Darder, M. Baltodano, \& R. D. Torres (Eds.). The critical pedagogy reader. New York: Routledge.

GoI (Government of India). (2011). Census data. New Delhi: Ministry of Home Affairs. Government of India

Govinda, R. (2002). India education report. London: Oxford University Press.

Gramsci, A. (1971). Selections from the prison notebooks. London: Lawrence and Wishatr.

Green, M. (2002). Gramsci cannot speak: Presentation and interpretations of Gramsci concept of the subaltern. Rethinking Marxism. 14 (3), 1-24.

Guptha,V. (2012). Pluralism versus contested identities, Seminar, October.

Harrison, B. \& Papa, R. (2005). The development of an indigenous knowledge program in a new Zealand Maori-language immersion School. Anthropology and Education Quarterly, 36(1). 57-72.

Heredia, R. C. (1992). Tribal education for community development. New Delhi: Concept Publishing Company.

Heredia, R C. (1995). Tribal education for development: Need for a liberative pedagogy for social transformation. Economic and Political Weekly, 30(16). 891-897.

Heredia, R. C. (1995a). Education and mission: School as agent of evangelisation. Economic and Political Weekly, 30(37), 2332-2340.

Janu, C. K. (2017). Manushyare Pariganikkan Keralam Padichittilla (Malayalam, Interview). Yukthirekha, 32(4). 22-27.

Jena, D. (1991). Socio-cultural constrains in tribal education. In P. RabindraNath, \& J. Lalitendu (Eds.) Tribal demography in India. New Delhi: APH Publishing House. Kannabiran, K. Constitutional Geographies and Cartographies of Impunity. Economic and Political Weekly. 51(44-45), 92-100.

Krishnaswami, N. (2001). Decolonizing education in India. In P. Adesh (Ed), Decolonization - A search for alternative. New Delhi: Creative Books.

Kumar, K. (1985). Education experiences of the scheduled castes and tribes. In S. Chandra Shukla \& K. Kumar (Eds.), Sociological perspectives in education. New Delhi: Chanakya Publications. 
Kumar, K. (1989). Textbooks and educational culture. Economic and Political weekly. 21 (30), 1236-1240.

Kumar, K. (1991). Political agenda of education. New Delhi: Sage Publications. Lohia, R. (1963). Marx, Gandhi, and socialism. Hyderabad, India: Navahind.

Manmar, M., \& Madhu, P. (1999). Indian education since independence. New Delhi: Vikas Publishing House.

Manojan, K. P. (2017). Constructing the drop-out childhood: Implications for formal schooling among Paniyars in Kerala. Man in Society, 24, 72-84.

Manojan, K. P. (2018). Indigenous knowledge in education: A study among Paniya tribes in Kerala. Journal of Social Work Education and Practice. 3(1), 43-55.

Manojan, K. P. (2018a). Curriculum pedagogy and formation of subjectivities: Adivasi childhood and conflicts in formal schooling, Kerala. Unpublished Ph.D. thesis submitted to Centre for Human Rights, University of Hyderabad. (India).

Manojan, K. P. (2019). Capturing the Gramscian project in critical pedagogy: Towards a philosophy of praxis in education. Review of Development and Change. 24(1). 123-145.

Mauro, F., \& Hardison P.D. (2000). Traditional knowledge of indigenous and local communities: International debate and policy initiatives. Ecological Applications, 10(5), 1263-1269.

Mayo, P. (2010). Gramsci and educational thought. UK: Willey Blackwell.

McLaren, P. \& Giroux, H. A. (1995). Social theory and education. New York: SUNY Press. McLaren, P. (2009). Critical pedagogy: A look at the major concepts. In A. Darder, M. Baltodano, \& R. D. Torres (Eds.), The critical pedagogy reader. New York: Routledge. Mishra, B.C. (1996). Education for tribal children. Haryana: Discovery Publishing House.

Nambissan, G., \& Srinivas, R. (2013). Sociology of education in India. New Delhi: Oxford University Press.

Nambissan, G. B. (1994). Language and schooling of tribal children: Issues related to medium of instruction. Economic and Political Weekly, 29 (42), 2747-2754.

Nambissan, G. B. (2002). Equity in education? Dalits and the State, 79.

Narayana, D. (2010). Educational deprivation of scheduled tribes in Kerala. Paper presented at Centre for Development Studies Conference, Paniya Sadassu, Wayanad, Kerala, March 13-15.

Ommen, T. K (2012). Ideology, culture and structure. Seminar, October.

Pal, A., Nagar, A. R. S., \& Chakraborty, T. (2001). Decolonisation: A search for alternatives. New Delhi: Creative Books.

Panikar, K. N (2006). An agenda for cultural action. Haryana: Three essay Collective. Patel, S. (1991). Tribal education in India: A case study of Orissa. New Delhi: Mithal Publications.

Pinto, A. (2004). Education and democracy in India: Contribution of the christian missionaries In A.V. Chatterjee (Ed.), Education and democracy in India. New Delhi: Manohar Publishers.

Pradhan, S. (2004). Educational deprivation of STs in India. In D.S Saha., \& S.S Yathindra (Eds.), Tribal issues in India. New Delhi: Rawath Publications.

Radhakrishna, M. (2016). First-Citizens: Studies on adivasis, tribals, and indigenous peoples in India. New Delhi: Oxford University Press. 
Rani, M. (2009). I Will Not attend school: Listen what ethnic children say. Vanyajati Vol.2 (April). 8-13.

Rege, S. (2010). Education as Trutiya Rathna: Towards phule - Ambedkarite feminist pedagogical practice. Economic and Political Weekly, 14 (44), 88-98.

Sachidanandha. (1999). Education of the scheduled castes and tribes. In M. Mukhopadhyay, \& M. Parhar (Eds.), Indian Education: Development since independence. New Delhi: Vikas Publishing House.

Santhosh, R. (2008). Mapping the ethno history of Paniyan: Some preliminary reflections. Indian Anthropologist, 38(1), 61-76.

Sarangapani, P. M. (2003). Constructing school knowledge: An Ethnography of learning in an Indian Village. New Delhi: Sage.

Sarangapani, P. M. (2003a). Indigenizing curriculum: Questions posed by Baiga vidya. Comparative Education, 39(3), 199-209.

Semali, L.M., \& Kincheloe J.L. (1999). Introduction chapter. In Ladislaus M. Semali., \& Joe L. Kincheloe (Eds.), What is indigenous knowledge? Voices from the academy. New York: Falmer Press.

Shaw, B.V. (2005). Education and social change among tribals in India. In Pariyaram, \& M. Chacko (Eds.). Tribal communities and social change. New Delhi: Sage.

Shor, I. (1993). Education as politics. In P. McLaren, \& P. Leonard (Eds.), Paulo Freire: A critical encounter. London: Routledge.

Singh, A. K. (1994). Drop-out from primary schools in tribal India: A case study of the Ho in Parampancho, West Singhbhum. Unpublished Ph.D. thesis submitted to the Department of International and Comparative Education (Institute of Education), University of London.

Singh, A. K. (1995). The cultural construction of home and school knowledge in tribal India. Prospects, 25 (4), 737.

Smith, L.T. (1999). Decolonizing methodologies: Research and indigenous people. London: Zed.

Smith, L.T. (2005). Building a research agenda for indigenous epistemologies and education. Anthropology and Education Quarterly, 36(1), 93-95.

Spivak, G.C. (1988). Can the subaltern speak? In C. Nelson., \& L. Grossberg (Eds.), Marxism and the interpretation of culture, Urbana: University of Illinois Press.

Sridhar, K. K. (1996). Language in education: Minorities and multilingualism in India. International Review of Education, 42 (4), 327-347.

Sujatha, K. (2002). Education among scheduled tribes. In R. Govinda (Ed.), India education report. London: Oxford University Press.

Sundar, N. (2002). Indigenise, nationalise and spiritualise: An agenda for education?. International Social Science Journal, 173, 373-383.

Sundar, N. (2010). Educating for inequality: The experiences of India's 'indigenous' citizens. Asian Anthropology, 9(1), 117-142.

Sunny, Y. (2014). Knowledge and the politics of education. Economic and Political Weekly, 49 (50), 103-124.

Teltumbe, A. (2018). Identity politics and the annihilation of castes. Seminar (Gandhi Special Issue). October.

Thomas, P. D. (2013). Hegemony, passive revolution, and the modern Prince. Thesis Eleven, 117(1), 20-39. 
Varghese R. (2015). Jayichavar thottu pokunna idam (Malayalam). Onnipu Masika. July.

Wringe, C. (1984). Democracy schooling and political education. London: George Allen \&Unwin.

Xaxa, V. (1999). Transformation of tribes in India: Terms of discourse. Economic and Political Weekly, 34(24), 1519-1524.

Xaxa, V. (2016). Formation of adivasi/indigenous people's identity in India. In M. Radhakrishna (Ed.), First citizens: Studies on adivasis, tribals, and indigenous peoples in India (pp.33-52). New Delhi: Oxford University Press.

Zene, C. (2013). The political philosophies Antonio Gramsci and B. R. Ambedkar. London: Routledge.

\section{Acknowledgment:}

Note: An earlier version of this paper was presented at a national workshop on Caste, Experience and Poverty of Education held at the Manipal Centre for Philosophy and Humanities (Karnataka, India) on 8- 9 December 2014. I thank my Ph.D. supervisor Prof. Arun Kumar Patnaik for his guidance in writing this paper and Anandan Paithalen for his acquaintance.

\section{Author:}

Manojan K.P., Ph.D.

Tuljapur Campus

Tata Institute of Social Sciences

School of Rural Development

Maharashtra

India

413601

Email:kpmanoj284@gmail.com 